REVISTA DE DERECHo UNED, NÚM. 7, 2010

\title{
LA EVOLUCIÓN DEL CONCEPTO DE ORDEN PÚBLICO A TRAVÉS DE LAS CONSTITUCIONES ESPAÑOLAS HASTA 1812
}

\author{
Salvador Iglesias Machado \\ Doctor en Derecho \\ Letrado del Consejo Consultivo de canarias
}

Resumen: El orden público es un fenómeno social producto de un proceso cambiante, dinámico. No constituye un concepto inmutable. Está vinculado a las vicisitudes políticas y sociales de cada momento histórico. Este trabajo pretende realizar un somero estudio de la evolución y contenido del concepto de orden público en el Estatuto de Bayona y en la Constitución Española de 1812, y de la influencia de dichos textos legales, así como de los sistemas políticos que configuran, en el concepto de «orden público».

Palabras clave: Orden público, Seguridad, Policía, Justicia, Constitución de Bayona, Constitución de Cádiz.

Abstract: Public order is a social phenomenon resulting from a dynamic process of change. It is not a fixed concept, but is rather linked to the political and social problems existing at any given moment in history. The aim of this study is to make a brief analysis of the evolution and content of the concept of public order contained within both the Statutes of Bayonne and the Spanish Constitution of 1812, and of the influence of these legal texts, as well as of the political systems they make up, on the concept of public order.

Key words: Public Order, Security, Police, Justice, Constitution of Bayonne, Constitution of Cadiz.

Sumario: I.- Introducción. II.- La Constitución de Bayona de 1808 y su entorno histórico. III.- El texto de Bayona y el orden público. IV.- El Sistema de seguridad, Policía y Justicia. IV.1.- El sistema de seguridad. 
IV.2.- La Policía. IV.3.- La Justicia. V.- La Constitución de 1812 y su entorno histórico. VI.- El Texto de 1812 y el orden público. VII.- El sistema de Seguridad, la Policía y la Justicia. VII.1.- El sistema de seguridad. VII.2.-La Policía. VII.3.- La Justicia. VIII.- Conclusiones.

\section{I.- INTRODUCCIÓN}

El orden público es un proceso dinámico, sujeto a evolución en el tiempo, se trata de un fenómeno social amplio y complejo, que desborda el ámbito jurídico, pese a que el concepto tiene para las ciencias jurídicas un indudable interés y desempeña un papel concluyente en el ámbito del Derecho Público. Su complejidad y amplitud es tal que en el mismo lenguaje jurídico - más aún en el lenguaje coloquial, periodístico o político- $\mathrm{y}$, en función del momento histórico al que nos refiramos, puede significar dos cosas muy diferentes.

El orden público no constituye un concepto inmutable, atemporal, pues está vinculado a las vicisitudes políticas y sociales de cada momento histórico y a la sociedad misma, con sus correspondientes valores culturales, morales y religiosos. Nos podemos referir al orden público material, el orden en la calle, la tranquilidad pública sin ningún tipo de alteración de la normalidad, la protección de los peligros del hombre y de la naturaleza, de prevenir y evitar los desórdenes, el orden público es el estado de hecho opuesto al estado de hecho que es el desorden. Es decir, una situación exterior de paz y tranquilidad públicas $^{1}$. O referirnos al orden general de la sociedad en sentido amplio. Para Izu Belloso ${ }^{2}$ el orden público así entendido, es una cláusula de cierre del ordenamiento, un criterio interpretativo puesto en manos de los jueces para resolver en último caso.; según Doral ${ }^{3}$, es una noción variable según las épocas, los países y los regímenes políticos de cada nación; y para Guaita ${ }^{4}$, el concepto de orden público es sin duda uno de los más contingentes y plásticos que ofrece la Ciencia del Derecho.

Es por ello que, a veces, se produce una cierta confusión cuando el concepto aparece en un texto constitucional o legal. Como vere-

\footnotetext{
${ }^{1}$ HAURIOU, Précis élémentaire de Droit administratif, París, 1926

${ }^{2}$ IZU BELLOSOS, Miguel José, Los conceptos de orden público y seguridad ciudadana, Cívitas, Revista Española de Derecho Administrativo, 1988

${ }^{3}$ DORAL, José Antonio, La noción de orden público en Derecho Civil español, Ediciones Universidad de Navarra, SA, Pamplona 1967,

${ }^{4}$ GUAITA, Aurelio, Derecho Administrativo especial, Tomo II, Zaragoza, 1965
} 
mos, este concepto de orden público se recoge en el constitucionalismo español y lo que entiende por tal la Constitución de 1812, por ejemplo, tiene una interpretación conceptual muy diferente a la que se deriva de la Constitución de 1978. En ésta, parece haber sido abandonado el concepto de orden público por cuanto se refiere a la misión de las Fuerzas y Cuerpos de Seguridad, sustituyéndolo por el de seguridad pública o seguridad ciudadana. No se trata de que el legislador haya buscado una nueva denominación para obviar el concepto tradicional desprestigiado por el régimen político anterior, sino de un cambio conceptual de gran alcance, que ha trascendido al ordenamiento jurídico español.

Pretende este trabajo realizar un somero recorrido por la historia de España en los periodos comprendidos entre las dos Constituciones objeto de estudio y observar la influencia que las ideas políticas del poder establecido, las épocas y, sobre todo, los fines que persigue el Estado, han ejercido sobre la elaboración del concepto, su alcance y sentido. Cada sociedad organiza las instituciones en función del ideal que declara, las finalidades que persigue y de los valores que quiere promover, que siempre responden a los intereses del poder establecido ${ }^{5}$.

Así, en el ideario del Estado Liberal prima la libertad sobre la seguridad y la no intervención del Estado tanto como la permisividad con tal de garantizar aquella. Potencia el pleno desarrollo de relaciones e iniciativas y utiliza el poder en relación con el orden público enfrentándose a cualquier forma exterior de desorden material. El Estado se convierte en guardián manteniendo el orden para que cada uno sea libre de sus actos. La legislación se hace imperativa para defender los principios del orden social y económico y su sistema de valores.

El Estado liberal entra en crisis al no poder superar las dificultades que se presentan, sobre todo las de tipo económico derivadas de las situaciones de monopolio. El Estado no puede permanecer pasivo, ha de intervenir si no quiere correr el riesgo de desaparecer a cuenta de las inclemencias del funcionamiento del libre mercado y las desigualdades que provoca. El Estado no puede permanecer en su papel de guardián, ha de procurar también el bienestar, para lo cual ha de intervenir.

${ }^{5}$ DELGADO AGUADO, J. y GARCÍA MADUELL, J. Seguridad Ciudadana y función policial Estudis i recerques, Protección Ciudadana, Ayuntamiento de Barcelona 1994. 
El mundo contemporáneo exige la intervención del Estado para establecer el orden social, las leyes imperativas se generalizan, controlan la actuación administrativa, pero van limitando la libertad de los individuos. La identificación entre orden público y ley imperativa se vuelve peligrosa; para evitar la simple identificación de orden público con voluntad del Estado se hace necesario buscar un concepto de orden público que lo distinga de la ley imperativa6.

Durante mucho tiempo, el concepto de orden público ha venido utilizándose para facilitar a los poderes públicos la habilitación necesaria para ejercer facultades imperativas y potenciar su campo de actuación. Es el marco adecuado que justifica la actuación e intervención estatal.

Soy consciente de la limitación de mi intento al pretender apuntar algunas notas que nos puedan orientar a determinar el vínculo del concepto de orden público con el sistema político reinante, del uso que del concepto se hace en las respectivas Cartas Magnas y las considerables oscilaciones a lo largo de la historia constitucional de España. Por ello ruego al lector que lo tenga como una mera aproximación a tan osado propósito. Para ello, haremos un repaso por los textos de las citadas Constituciones y el momento histórico y político en que se redactan.

\section{II.- LA CONSTITUCIÓN DE BAYONA DE 1808 Y SU ENTORNO HISTÓRICO.}

El «Acte Constitutionnel de l'Espagne», aprobada en Francia el 8 de julio de 1808, se inspira en el modelo de Estado constitucional Bonapartista. En realidad, aunque se trate del primer texto constitucional escrito y codificado, que estuvo en vigor en España, no se puede considerar una verdadera Constitución, porque ni fue redactada por españoles ni tuvo vigencia en todo el territorio. Tal es así, que más que por Constitución, al texto se le conoce por el Estatuto de Bayona. Tuvo un carácter afrancesado como sus defensores: los liberales moderados. Puede considerarse como una Carta otorgada por Napoleón, que ostentaba el poder a través de su hermano José Bonaparte. Se presentó en Francia a 65 diputados españoles a los que se les impuso un texto en francés, sin posibilidad de corregirlo. Siguiendo al profesor Oscar Alzaga Villamil, se trata de una Constitución flexible,

${ }^{6}$ IZU BELLOSOS, Miguel José, Los conceptos de orden público y seguridad ciudadana, Cívitas, Revista Española de Derecho Administrativo, 1988 
modificable mediante Ley. Para el profesor Joaquín Varela a pesar de su carácter autoritario, el Estatuto reconocía la libertad individual frente a detenciones arbitrarias, la libertad de imprenta, la igualdad fiscal y de fueros, la inviolabilidad de domicilio, la abolición del tormento, la supresión de privilegios y la promoción de los funcionarios de acuerdo con su mérito y capacidad. La protección de la libertad individual y de la libertad de imprenta se encomendaba al Senado, que, pese a su nombre, no era un órgano legislativo.

Es el momento en que entramos en la Edad Contemporánea, España también, aunque más lentamente, deja atrás el Antiguo Régimen basado en una sociedad fundamentalmente agrícola, estructurada en estamentos (Nobleza, Clero, grandes poseedores de la tierra y Estado Llano) que se asentaba en los privilegios de clase. Eran los tiempos de instituciones medievales como la Mesta, la Inquisición, los señoríos, los mayorazgos, etc.

Cuando ve la luz la Constitución, en 1808, la situación de la Hacienda española estaba bajo mínimos, los ingresos públicos eran la mitad de los gastos y la deuda pública equivalía a los ingresos de diez años. La situación socio-económica era difícil, las arcas del Estado estaban muy mermadas como consecuencia del sostenimiento de las guerras, la mala financiación pública, las epidemias ${ }^{7}$, la crisis agraria y por la crisis internacional.

En el aspecto cultural baste reproducir la opinión de Benimeli ${ }^{8}$ El retroceso que supuso para la cultura y la ideología ilustrada la implantación de una serie de medidas encaminadas a detener el pensamiento revolucionario francés se reflejó no sólo en la desaparición de una serie de prestigiosos periódicos, en la presencia de una fuerte censura, sino en el resurgir de un no despreciable número de publicaciones - como las de Fray Diego José de Cádiz, Hervás y Panduro, el P. Tragia, etc.- que constituyeron, en gran medida, lo que Herrero llama los orígenes del pensamiento reaccionario español.

La respuesta del Gobierno de España de manos de su primer ministro, Floridablanca, al peligro de contagio de las ideas revolucionarias fue aislar el país de cualquier influencia de dichas ideas. Se ce-

${ }^{27}$ A finales del reinado de Carlos III apareció la epidemia de tercianas, más tarde (1800) la fiebre amarilla y el 1804 el cólera, Datos obtenidos de FERRER BENIMELI, José Antonio, El fin del Reformismo, Crisis del Antiguo Régimen, De Carlos IV a Isabel II, Historia 16, Extra XXI

${ }^{8}$ FERRER BENIMELI, José Antonio, El fin del Reformismo, , Crisis del Antiguo Régimen, De Carlos IV a Isabel II, Historia 16, Extra XXI 
rraron las fronteras, se aplicó el máximo rigor al control de ciudadanos extranjeros en suelo español, se generalizaron los registros de barcos y buques, en especial los provenientes de Francia, se impuso una censura férrea sobre libros y cualquier otra forma de difusión escrita de las ideas burguesas vencedoras en el país vecino. Se organizó la persecución de los simpatizantes de la Revolución y para ello se utilizó la eficaz colaboración de la Inquisición acostumbrada a las persecuciones ideológicas-religiosas. Esta represiva institución renace con fuerza y se convierte en el mejor auxiliar de la policía.

El 21 de septiembre de 1789, Floridablanca remite al inquisidor general una Real determinación encargándole que recogiese todo impreso o manuscrito que se esparza relativo directa o indirectamente contra la subordinación y vasallaje, obediencia y reverencia a nuestro venerado monarca, y al vicario Jesús Cristo, por ser semejantes ideas antievangélicas y expresamente contra la doctrina de los Santos Apóstoles Pedro y Pablo. Las ideas influenciadas por el Despotismo Ilustrado estuvieron a punto de provocar la ruptura de relaciones con Francia en un momento de debilidad económica y militar española.

El Estatuto se promulgó en un momento de grave crisis de la Corona. El valido, Godoy, no gozaba del respeto del pueblo por sus intentos de acumular excesivo poder, por valerse de su amistad y relaciones con la Reina María Luisa para dominar la política de España, por la alianza con Francia y por las derrotas militares. Con el Tratado de San Idelfonso se renuevan con Francia los antiguos Pactos de familia y España, se obliga a luchar en alianza con ella contra Inglaterra. Costó la derrota de la Armada en el cabo de San Vicente y la pérdida de la isla de Trinidad, además de un importante déficit de Hacienda y el desprestigio del crédito internacional. Tal fue la situación creada, que en septiembre de 1798 se tuvo que proceder a vender los bienes raíces pertenecientes a hospitales, hospicios, casas de misericordia, de reclusión y de expósitos, cofradías, memorias, obras pías y patronatos de legos, cuyo importe se destinaba a la real caja de amortización.

En virtud del Tratado de Fontainebleau (octubre de 1807) España y Francia se unen para atacar Portugal, y bajo ese pretexto, cinco cuerpos de ejército penetran por los Pirineos y ocupan España, que queda bajo control de Napoleón. Cuatro días más tarde, Carlos IV dirige al país un manifiesto denunciando el complot de su hijo para destronarlo.

El malestar culminó con el Motín de Aranjuez (17 de marzo de 1808) contra Godoy y el mismo Rey, Carlos IV, quien se vio obligado 
a abdicar en favor de su hijo Fernando VII. Al cabo de dos días, Carlos IV anuló el decreto de abdicación y se trasladó a Francia para recuperar la Corona de España con la ayuda Napoleón. El 24 de marzo el príncipe Fernando convertido en rey hace su entrada en Madrid, y es invitado por Napoleón para acudir a Bayona. Fernando devolvió la corona a su padre y renunció a sus derechos de príncipe de Asturias, asimismo Carlos IV renunció a la corona en favor del emperador de Francia, quien, a su vez, designó como rey de España a su hermano José Bonaparte.

La intención de Napoleón era instaurar una monarquía moderadamente representativa y cautamente reformista mediante el instrumento de una constitución ${ }^{9}$

Todo esto ocurre en Marzo y el Estatuto se firma en julio, cuando en mayo había empezado la guerra de la Independencia. Se inicia un periodo de dualidad: dos bandos dominando cada uno parte del territorio nacional, con proyectos políticos diferentes, si no opuestos.

El 2 de mayo se produce el levantamiento del pueblo contra el ejército francés, una reacción de base netamente popular, de donde parte la guerra de la Independencia. El sistema empleado era la guerra de guerrillas, pero la victoria más sonora la conquistó el general Castaños en Bailén el 19 de julio. La situación bélica obligó a poner en marcha una nueva organización política surgida de las Juntas, que decidieron crear la Junta Central Suprema Gubernativa del Reino instalada en Aranjuez el 25 de septiembre.

En noviembre de 1808 entra Napoleón en Madrid, 250.000 hombres encuadrados en su ejército iniciarían la segunda fase de la guerra, que no daría fin hasta 1814.

La guerra de la Independencia lo condicionó todo. José I sin ejército, con la hacienda arruinada, aislado, sin apoyo suficiente del Emperador francés estaba abocado al fracaso. Pese a las medidas de gracia para los desertores y los que hubiesen luchado contra el Emperador y otras tendentes a atraer a los militares profesionales, fracasó en el empeño. Para disponer de un ejército propio tuvo que recurrir a mercenarios extranjeros, aún así no sobrepasó los 18.000 hombres ${ }^{10}$. Napoleón no le prestó la ayuda financiera necesaria, se quejaba su hermano que no entraba un real en el Tesoro, $1811 \mathrm{y}$

${ }^{9}$ ARÓSTEGUI SÁNCHEZ, Julio, Un nuevo sistema politico, Crisis del Antiguo Régimen, De Carlos IV a Isabel II, Revista Historia 16, Extra XXI

${ }^{10}$ ESPADAS BURGOS, Manuel, La soledad de un buen rey, La España de José Bonaparte, Revista de Historia 16, Año XII- No 147 
1812 fueron años de una gran hambruna en España. Ello justificó la necesidad de llevar a cabo la conocida desamortización para obtener recursos financieros y tesorería.

\section{III.- EL TEXTO DE BAYONA Y EL ORDEN PÚBLICO}

El concepto de orden público que existía hasta entonces en nuestro país era el correspondiente al Antiguo Régimen, el de un Estado absolutista. Concebido como fin es sí mismo, más preocupado en defender los intereses de quienes ostentan el poder y los privilegios de clase, que en garantizar la seguridad de la ciudadanía. Era una imposición del Estado a los ciudadanos por el que les procuraba cierta seguridad a cambio de adaptar su conducta a las normas establecidas.

No existe división de poderes y el Estado ejerce un gran control sobre los nacionales, sin que éstos puedan influir en la forma de ser gobernados. La pena tiene carácter expiatorio, constituye un castigo para el individuo, para cuya detención y confesión está justificado cualquier medio incluyendo la tortura y las encarcelaciones. A. Pergunson ${ }^{11}$ señala que: la noción de orden público en la sociedad civilizada es a menudo falsa porque deriva de una analogía con los objetos animados y muertos. Consideramos el movimiento y la acción como algo contrario a su naturaleza, pensamos que ésta no puede existir sin la obediencia, el secreto y un paso silencioso de los asuntos por las manos de un pequeño número de personas. La primera está formada por partes muertas y la segunda por las vivas. Cuando en una sociedad buscamos el orden en la simple no acción y tranquilidad, olvidamos la naturaleza y encontramos el orden de los esclavos, no de los hombres libres.

En el absolutismo, el Estado ejerce el poder sobre los individuos sin que exista ningún tipo de control sobre el sistema (policía, justicia, prisión, autoridades), mientras que los súbditos tienen que cumplir las leyes sin mediar un contrapeso al poder establecido, sin observancia del estado de derecho, sin división de poderes. El principio es que la prohibición es la regla, la libertad, la excepción. La libertad y la igualdad no son reconocidas como un valor, y menos como un valor superior del ordenamiento jurídico, quedan reducidas a mínimos en beneficio del orden público bajo cuyo pretexto se persigue

${ }^{11}$ Cita extraída del texto de DELGADO AGUADO, J, La policía, el conflicto social y las multitudes, Escuela de la Guardia Urbana de Barcelona 1980 
todo aquello que pueda debilitar al poder, todo lo que pretenda apartarse de la verdad doctrinaria a la que sirve. El orden público está concebido como instrumento de protección de las clases dominantes, una excusa para imponer las reglas del juego establecidas por el sistema.

El «Acte Constitutionnel de l'Espagne», o Estatuto de Bayona, venía influenciado por la Revolución Francesa y por las ideas del liberalismo burgués, lo que representaba un paso adelante muy significativo en cuanto a la concepción del orden público. Desde este momento habrá dos Españas enfrentadas entre sí, la controlada por José Bonaparte y la que no lo está. Ambas seguirán modelos políticos diferentes con conceptos opuestos de orden público.

El Estatuto suprimía las aduanas interiores, proclamaba la inviolabilidad del domicilio, la libertad personal, los derechos de los detenidos y de los presos, y la abolición del tormento. El 20. ${ }^{\circ}$ Acuerdo (12 de enero de 1810), suscrito por Lardizábal, José Pablo Valiente, Antonio Ranz de Romanillos, Alejandro Dolarea y Agustín Argüelles, establece:

Antes de proceder la Junta a la organización del Poder Judicial ha creído necesario comenzar el arreglo de esta grande obra en que estriba la libertad civil del ciudadano desterrando para siempre de la legislación Española la pena del Tormento. Y aunque en rigor esta disposición debia de ser más bien el objeto de una ley particular cuando se tratase de la reforma del Código criminal, que del acto de Constitución, a fin de desagraviar en parte a la humanidad y redimirla de la horrible vejación que ha sufrido por espacio de tantos siglos en la aplicación de esta pena, ha resuelto quede abolida por Ley fundamental y constitutiva del Reino, como igualmente todas las leyes que sobre esta manera de prueba tan bárbara y cruel como incierta y diametralmente opuesta al objeto de la Justicia disponen arrancar del reo la confesión de los delitos.

\section{IV.- EL SISTEMA DE SEGURIDAD, POLICÍA Y JUSTICIA}

\section{IV.1.- El Sistema de seguridad}

El sistema de seguridad de este momento histórico se sustenta en la autoridad del Rey que tiene a sus directas órdenes al Ejército para luchar contra toda clase de subversión en el territorio y contra las bandas armadas, el bandolerismo y los malhechores; y la Inquisi- 
ción, que no sólo juzgaba a los reos, sino que sirviéndose de una densa red de confidentes y de la colaboración ciudadana, investigaba los delitos. Un número inconexo y escasamente profesional de cuerpos de policía locales, comarcales y regionales dependientes en última instancia de las capitanías generales, intentaban dar tranquilidad en sus respectivos territorios.

En la España levantada en armas contra José Bonaparte, se organizaron Juntas Provinciales y, más tarde, la Junta Central. Pero embebida en la guerra poco pudo hacer en materia de seguridad, una de las pocas iniciativas que se pudo poner en marcha fue la Junta de Tranquilidad Pública cuyo objetivo no era otro que el de perseguir a los afrancesados y colaboradores del gobierno impuesto.

El sistema de José Bonaparte era diferente, dio los primeros pasos para establecer en España un sistema de seguridad y un modelo policial moderno a imagen y semejanza del modelo francés. En su breve y agitado reinado desarrolló un proceso de creación de ministerios y de adaptación de las estructuras del Antiguo Régimen al modelo diseñado en el Estatuto de Bayona. Desarrolló energías para reformar la organización territorial de España en departamentos, que se hacían coincidir con las antiguas provincias, las audiencias, las diócesis eclesiásticas y los distritos universitarios. Tales previsiones nunca llegaron a ponerse en marcha.

En virtud de Real Decreto del 6 de febrero de 1809, se crearon el Ministerio del Interior y el Ministerio de la Guerra, se suprimió el Consejo de Castilla. Se mantuvo vigentes la figura de los alcaldes de Casa y Corte solamente en Madrid y se creó unas Juntas Contenciosas para dar salida a los asuntos sin resolver por el Consejo de Castilla.

El Ministerio del Interior asumía las competencias políticas y administrativas del extinto Consejo de Castilla, entre ellas se encontraba la función de policía de los pueblos. El Ministerio de la Guerra entendía de la formación, organización, instrucción, administración, disciplina y movimientos de los ejércitos de Tierra, a más de las milicias provinciales, las urbanas y toda clase de gente armada que tenga por objeto la defensa de las costas o la tranquilidad del país ${ }^{12}$.

En 1808 se crea la Superintendencia de Policía General, en 1809 la Intendencia General de Policía y un Batallón de Policía y la Guardia Cívica. El mando de la nueva Policía lo asume un comisario en

12 ESPADAS BURGOS, Manuel, La soledad de un buen rey, La España de José Bonaparte, Revista de Historia 16, Año XII- No 147 
cada provincia. La pérdida de la guerra y la consiguiente marcha de España del monarca impuesto, dio al traste con todos estos bienintencionados proyectos. Debido a ello, tardaríamos medio siglo en adoptar el modelo policial francés inspirado en un modelo de seguridad y orden público radicalmente opuesto al español.

El artículo 27 del Estatuto de Bayona creaba el Ministerio de Policía General del reino, aunque tardó algo más en ponerse en marcha. Su cometido era la seguridad del Estado y sus competencias: proveer medidas para la seguridad del Estado, la custodia de las prisiones, y la censura de los periódicos.

\section{IV.2.- La policía}

La función policial durante los siglos XVII, XVIII y XIX, era realizada en lo fundamental por el Ejército. Existía un innumerable número de cuerpos policiales provinciales, comarcales y locales, también algunos regionales, inconexos, de escasa profesionalidad, salvo excepciones, con pocos recursos y efectivos, en ocasiones sus componentes compatibilizaban el servicio propio de la función policial con otro oficio, dichos cuerpos policiales resultaban muy limitados para enfrentarse con éxito a los problemas de inseguridad que se daban en las tierras y caminos del país. En realidad, la profesión de policía no estaba definida. Dependían, por lo general, de los Capitanes Generales o de las Audiencias, aunque alguna respondía al mando de un señor. Era la época dorada del bandolerismo, de los malhechores, que favorecidos por las circunstancias de inestabilidad política, el malestar popular, las crisis sociales y, también, por la falta de una institución policial, nacional y profesional, actuaban con casi total impunidad.

La policía no era más que un instrumento del poder, una vez que cumplió su cometido, a las órdenes del rey, de someter a la nobleza, ahora es sometida a una nueva manipulación: el rey la sigue utilizando para ejercer su poder absoluto. Al Príncipe no le conviene gobernar con el simple apoyo de su poder fáctico, puesto que le es mucho más rentable invocar un principio ideológico que haga más soportable a los súbditos la existencia del Poder. A cuyo efecto acude a la idea de la Policía, bien arraigada ya en la conciencia popular, pero remodelada conforme a una nueva versión. La Policía va a ser, a partir de este momento, el medio técnico de la intervención administrativa que asegura la felicidad de los individuos que la padecen. $O$ lo que es lo mismo: la Policía no interviene en beneficio del Príncipe 
sino en el de los súbditos. Con lo cual, naturalmente éstos van a aceptarla mucho mejor ${ }^{13}$

Entre los cuerpos policiales locales, comarcales o regionales podemos citar: Miñones de Vizcaya y Álava, Guardia del Reino de Aragón, Compañía de ballesteros del Centenar de Valencia, los Guardias de la Costa de Granada, las Milicias Locales de Andalucía, las Escuadras de Cataluña, la Compañía de Escopeteros del Centenar de Tarifa, Caudillatos de Galicia, Rondas Volantes de Cataluña, los Somatenes, Fuerzas Auxiliares de Madrid. La situación del orden público empeora cuando estos cuerpos de seguridad se tienen que incorporar a filas para participar en la guerra contra el invasor, viéndose obligados a abandonar su labor policial genuina.

En un intento de poner orden y eficacia en el campo de la seguridad y dar respuesta al crecimiento poblacional y territorial de Madrid, mediante Real Decreto de 17 de marzo, de 1782, se crea una Superintendencia General de Policía para Madrid con objeto de velar en la ejecución de las leyes, autos acordados, bandos, decretos y demás providencias tocantes a la policía material y formal; corrigiendo y multando a los contraventores... Se decidió que la Sala de Corte, Alcaldes de Cuartel y de Barrio, el de la Comisión de Vagos, el corregidor de Madrid y sus tenientes, y demás obligados a cuidar de la policía en lo material y formal, continuasen acumulativamente, sin estorbar al superintendente general... obedeciendo sus providencias; y que estas facultades y jurisdicción del superintendente fuesen por vía económica, gubernativa y executiva, como son todas las leyes y bandos de policía, sin apelación o recurso,- pues cualesquiera quejosos en casos graves podrían recurrir a la Real Persona, o directamente por medio de la Secretaría de Estado, o por medio del Gobernador del Consejo; y en los casos en que de los procedimientos resultase descubrirse algún delito, perjuicio de tercero, o motivo de formal instancia judicial, cuidaría el superintendente de remitirlo todo al juez o Tribunal correspondiente ${ }^{14}$.

La Policía, dice el autor, es jurisdiccionalmente autónoma, como zona excluida de la intervención de cualquier Tribunal ordinario. La legislación es, en este punto, reiterada: la Cédula del Consejo de 13 de junio de 1792 (a consulta de 16 de mayo-, ley 11, tít. XXII, Lib. 3 de

${ }^{13}$ NIETO, Alejandro, Algunas precisiones sobre el concepto de Policía, Revista de Administración Pública 081, 1976

${ }^{14}$ GIL MÁRQUEZ, Tomás, El sistema de seguridad publica en la constitución española de 1978, Memoria de la tesis doctoral dirigida por Montserrat NEBRERA, Universitat A. Oliba CEU, Facultat de Ciències Socials 
la Novísima Recopilación) dispone que «será cada Alcalde de Casa y Corte el Intendente particular de Policía en su distrito y su Juez ordinario para las ocurrencias y comodidad de los vecinos... teniendo siempre presente el no confundir ni comprometer ésta (la policía) con lo que mereciese rigurosa administración de Justicia por su entidad, consecuencia y vindicta pública».

Carlos IV había dictado disposiciones preventivas sobre armas, espectáculos, juego, vagos, etc. y anteriormente, en 1805, había sancionado el libro XII de la Novísima Recopilación en el que se parte del principio de que para asegurar la felicidad pública es preciso mantener en todo momento la autoridad y el cumplimiento de las leyes encaminadas a contener los espíritus inquietos, enemigos del sosiego público. Conecta el concepto de orden público material con el de felicidad pública. También había suspendido todos los periódicos que no fueran de noticias o avisos, por RD de 14 de febrero de 1971, que renovaría en 1804.

En 1809 se creó en Madrid el Batallón de Policía, cuerpo uniformado para ejecutar las órdenes gubernativas de policía, unos meses después se constituyeron las Milicias Urbanas en Castilla la Nueva con una misión más militar que policial, pues su objeto fue luchar contra las partidas militares francesas y, por último, la Guardia Cívica en 1810 en Andalucía y también en Madrid para cuidar de la tranquilidad interior de los pueblos, con vocación de extenderse por toda España. Ninguna de estas instituciones sobrevivió a la Constitución de 1812.

\section{IV.3.- La justicia.}

El Título XI del Estatuto de Bayona lleva por rúbrica «del Orden Judicial», comprende los artículos 96 a 114. La justicia era aplicada por los regidores en todas las provincias menos en Madrid que se impartía a través de la Sala de los Alcaldes de Casa y Corte, la ciudad estaba dividida en cuarteles dirigidos por un alcalde que hacía las veces de juez a cuyas órdenes tenía a un número de alguaciles, que llevaban a cabo funciones de policía administrativa y de seguridad. Eran responsables de la seguridad de las personas de su cuartel y de la armonización de la vida vecinal, para ello podían adoptar medidas de vigilancia y control, imponer multas y cualquier otra medida relacionada con esa importante función. En 1739 se puso bajo sus órdenes el cuerpo de Inválidos Hábiles, compuesto por soldados licenciados por haber quedado inhábiles para el combate, pero útiles para funciones de menor esfuerzo y riesgo. 


\section{V.- LA CONSTITUCIÓN DE 1812 Y SU ENTORNO HISTÓRICO}

La importancia histórica de esta Constitución -llamada la Pepa por haberse promulgado el 19 de marzo, día de San José- es debido a ser la primera que se promulga en España. De corta vigencia, fue considerada como una de las más liberales de la época. Adquirió un gran valor simbólico de libertad, que no sólo alcanzó a la España metropolitana, sino que se extendió por América y resto de colonias españolas. Se tradujo a varios idiomas y Europa tomó buena nota de su texto para verlo con admiración y respeto o para criticarlo por haber traspasado los límites del progresismo.

El objetivo de las Juntas aglutinadas en torno a la Junta Suprema General Gubernativa era restaurar la monarquía borbónica. Pronto se pudo comprobar que la acción de las Juntas podía ser útil para presentar batalla a las tropas napoleónicas, organizar las guerrillas, impulsar al Ejército, pero no para administrar debidamente a la sociedad. La falta de un orden institucional se puso de manifiesto, sobre todo al comparar la acción de las Juntas con la del gobierno de José Bonaparte, quien, con la colaboración de españoles ilustrados, llevaba a cabo reformas sustanciales, entre ellas, algunas muy importantes relacionadas con el orden público. Estas circunstancias llevaron a que las Juntas vieran la necesidad de convocar unas Cortes sin tener aún claro cuál iba a ser el futuro político español. Había entonces dos corrientes bien opuestas: la que defendía la opción de volver a la situación previa al estatuto de Bayona, o sea, a la monarquía absoluta, corriente liderada por Jovellanos, y la que pretendía romper con el pasado y promulgar una nueva Constitución, cuyo principal defensor era Agustín de Argüelles. Éstos vieron en la crítica situación de España la oportunidad de acabar con el Antiguo Régimen y promulgar una Constitución que limitara los poderes reales y abriera el campo de las libertades.

La primera reunión de las Cortes fue el 24 de septiembre de 1810. Las deliberaciones se enquistaron debido a la pretensión de una nueva organización territorial para las colonias de ultramar; a las reticencias de los partidarios de Jovellanos a dar a luz una Constitución de corte liberal, y a la presión de la Iglesia. La Constitución transformó el imperio colonial en provincias españolas y desterró para aquellos españoles de ultramar el absolutismo, considerando también a los indígenas ciudadanos españoles. Las representaciones americanas no consiguieron su pretensión de que el Estado se organizara conforme al modelo federalista. La nación española es la reunión de los españoles de ambos hemisferios, reza el artículo primero. 
Pero en aquella situación de medio aislamiento le resulto fácil a los liberales vencer las resistencias. Y al parecer ese fue el error, no tener en cuenta la realidad de aquella España, que no estaba preparada para dar un salto político de tanto calado. Nuestro país no había experimentado los cambios sociales y políticos que permitieran asumir el espíritu de la nueva Constitución. No hubo consenso con los conservadores, ni con la Corona y tampoco con la Iglesia.

La Constitución de 1812 nació con los días contados. Aún faltaría más de medio siglo, para que viera la luz otra Constitución del mismo corte. Y más de siglo y medio para que se consolidara en nuestra sociedad una Constitución democrática y un Estado Social y Democrático de Derecho, como la de 1978 que proclama como valores superiores de su ordenamiento jurídico la libertad, la justicia, la igualdad y el pluralismo político. Emilia Ramírez ${ }^{15}$ afirma que la Constitución era técnicamente perfecta para una comunidad de ciudadanos preparados económica y culturalmente, para el ejercicio de su ciudadaní; pero resultaba evidentemente inadecuada a las condiciones reales del pueblo español a comienzos del siglo XX. Por otra parte, Martín- Retortillo ${ }^{16}$ entiende que (...) un texto que casi jugará su mayor baza en el terreno de la utopía como desencadenante de aspiraciones (...). Nada de esto es óbice para que la Constitución de 1812 no constituyera un hito democrático y sirviera de inspiración para las constituciones españolas de corte liberal y democrático, incluida la actualmente vigente, para otras constituciones europeas y para las nuevas naciones americanas tras su independencia. Las Cortes de Cádiz tuvieron carácter popular. Las sesiones fueron públicas, excepto aquellas en las que se abordaban cuestiones secretas de Estado. Es la primera vez en la que se produjo una identificación entre el concepto de nación y pueblo español, lo que no volverá a ocurrir hasta la Constitución de 1869 , y más tarde se repetiría en la de 1931 y en la vigente de 1978. «La soberanía reside esencialmente en la nación, y por lo mismo pertenece a ésta exclusivamente el derecho de establecer sus leyes fundamentales» (art. 13)

Es una Constitución larga, consta de 384 artículos, y rígida al disponer de un complicado procedimiento de reforma. No esperaban

\footnotetext{
${ }^{15}$ RAMÍREZ, Emilia, Conferencia en conmemoración del Día de la Constitución, Aproximación a las Constituciones españolas desde 1808, www,educa,madrid,org/web/ies, maranon,lacala/revista

${ }^{16}$ MARTÍN RETORTILLO BAQUER, Lorenzo, Notas para la historia de la noción de orden público, Estudis i recerques, Policía y Constitución, Serie Protección ciudadana $\mathrm{n}^{\circ} 1$, Ayuntamiento de Barcelona, 1987
} 
los legisladores que en sólo dos años, a Fernando VII no le bastaría más que un decreto para hacerla desaparecer.

En el Título I se incorporan los principios básicos del liberalismo que rompen con el absolutismo: libertad e independencia de la nación española, soberanía nacional, derechos civiles, derecho de propiedad. También establecía el sufragio universal indirecto y masculino, la monarquía constitucional, la separación de poderes, la libertad de imprenta, el reparto de tierras y la libertad de industria. Cuenta con una detallada exposición de derechos y libertades individuales. El Parlamento es unicameral, se establece la independencia de las Cortes con respecto al Rey y demás órganos del Estado. La Constitución de 1812 suprimió la representación por estamentos, estableciendo que hubiera un diputado por cada 60.000 habitantes elegidos por método indirecto. Podían ser diputados todos aquellos españoles hombres, mayores de 25 años y poseedores de una determinada renta.

El $20^{\circ}$ Acuerdo (12 de enero de 1810) firmado por Manuel de Lardizábal, José Pablo Valiente, D. Antonio Ranz de Romanillos, D. Alejandro Dolarea, D. Agustín Argüelles, decía: Antes de proceder la Junta a la organización del Poder Judicial ha creído necesario comenzar el arreglo de esta grande obra en que estriba la libertad civil del ciudadano desterrando para siempre de la legislación Española la pena del Tormento. Y aunque en rigor esta disposición debía de ser más bien el objeto de una ley particular cuando se tratase de la reforma del Código criminal, que del acto de Constitución, a fin de desagraviar en parte a la humanidad y redimirla de la horrible vejación que ha sufrido por espacio de tantos siglos en la aplicación de esta pena, ha resuelto quede abolida por Ley fundamental y constitutiva del Reino, como igualmente todas las leyes que sobre esta manera de prueba tan bárbara y cruel como incierta y diametralmente opuesta al objeto de la Justicia disponen arrancar del reo la confesión de los delitos.

Era una conquista sin precedentes en la defensa de los Derechos Humanos, por desgracia duró poco, dos años después Fernando VII iniciaría una persecución sangrienta contra sus adversarios políticos, los liberales. Sin embargo, es restrictiva en cuanto a la libertad religiosa: La religión de la Nación española es y será perpetuamente la católica, apostólica y romana, única y verdadera. La Nación la protege por las leyes sabias y justas y prohíbe el ejercicio de cualquier otra.

Proclama la soberanía nacional y el reconocimiento de derechos individuales, para lo que limita derechos al Rey en un claro intento de superar la monarquía absoluta, aunque, a pesar de ello, mantuvo 
importantes competencias en sus manos, cuestión criticada por un sector del liberalismo. Después de sancionar que la persona del Rey es sagrada e inviolable, y no está sujeta a responsabilidad, el artículo 170 determina que la potestad de hacer ejecutar las leyes reside exclusivamente en el Rey, y su autoridad se extiende a todo cuanto conduce a la conservación del orden público en lo interior, y a la seguridad del Estado en lo exterior, conforme a la Constitución y a las leyes.

Además de estas prerrogativas le correspondían, entre otras, las facultades siguientes: expedir los decretos, reglamentos e instrucciones conducentes para la ejecución de las leyes; cuidar de que en todo el reino se administre pronta y cumplidamente la justicia; declarar la guerra, y hacer y ratificar la paz, dando después cuenta documentada a las Cortes; nombrar los magistrados de todos los tribunales civiles y criminales, a propuesta del Consejo de Estado; proveer todos los empleos civiles y militares; conceder honores y distinciones de toda clase; mandar los ejércitos y armadas, y nombrar los generales; disponer de la fuerza armada, distribuyéndola como más convenga; dirigir las relaciones diplomáticas y comerciales con las demás potencias, y nombrar los embajadores, ministros y cónsules; cuidar de la fabricación de la moneda; decretar la inversión de los fondos destinados a cada uno de los ramos de la administración pública; indultar a los delincuentes; hacer a las Cortes las propuestas de leyes o de reformas; conceder el pase, o retener los decretos conciliares y bulas pontificias con el consentimiento de las Cortes, oyendo al Consejo de Estado o al supremo tribunal de justicia; nombrar y separar libremente los secretarios de Estado y del Despacho. Es decir, quedaba en sus manos el poder ejecutivo.

Las restricciones de la autoridad del Rey se concretan en el artículo 172 y concordantes del texto constitucional: «no puede el Rey impedir bajo ningún pretexto la celebración de las Cortes en las épocas y casos señalados por la Constitución, ni suspenderlas ni disolverlas, ni en manera alguna embarazar sus sesiones y deliberaciones. Sin conocimiento de las Cortes no podrá: ausentarse del reino y, si lo hiciere, se entiende que ha abdicado la Corona; enajenar, ceder, renunciar o en cualquiera manera traspasar a otro la autoridad real, ni alguna de sus prerrogativas; enajenar, ceder o permutar provincia, ciudad, villa o lugar, ni parte alguna, por pequeña que sea, del territorio español; hacer alianza ofensiva, ni tratado especial de comercio con ninguna potencia extranjera; obligarse por ningún tratado a dar subsidios a potencia extranjera; ceder ni enajenar los bienes nacionales; imponer por sí directa ni indirectamente contribuciones, ni hacer pedidos bajo cualquier nombre o 
para cualquiera objeto que sea; conceder privilegio exclusivo a persona ni corporación alguna. No puede el Rey tomar la propiedad de ningún particular ni corporación, ni turbarle en la posesión, uso y aprovechamiento de ella; y si en algún caso fuere necesario, no lo podrá hacer, sin que al mismo tiempo sea indemnizado; privar a ningún individuo de su libertad, ni imponerle por sí pena alguna. El Rey antes de contraer matrimonio dará parte a las Cortes para obtener su consentimiento; y si no lo hiciere, entiéndase que abdica la Corona».

El padre Vélez ${ }^{17}$ criticaba estas restricciones: (...) el 170, que declara residir en el rey exclusivamente la potestad de hacer ejecutar las leyes: es decir, el rey que gobierne por la constitución no es más que un simple ejecutor de sus leyes en todo dependiente de la nación, o un esclavo de sus soberano el pueblo, o un mozo o dependiente de una gran señora, obligado siempre a pedirle licencia de cuanto haga en su casa, y si no, expuesto a que se le llame a cuenta, se le exija por mil títulos la responsabilidad (...)

La Constitución rompe con los inconvenientes de un ordenamiento jurídico caótico, fragmentado, con diferentes jurisdicciones. Así se manifiesta Argüelles en el Discurso Preliminar: La igualdad de derechos proclamados en la primera parte de la Constitución a favor de todos los naturales originarios de la monarquía, la uniformidad de principios adoptada por V.M en toda la extensión del vasto sistema que se ha propuesto, exigen que el código universal de leyes positivas sea uno mismo para toda la nación, debiendo entenderse que los principios generales sobre los que han de estar fundadas las leyes civiles y de comercio no pueden estorbar ciertas modificaciones que habrán de requerir necesariamente la diferencia de tantos climas como comprender la inmensa extensión del imperio español y la prodigiosa variedad de sus territorios y producciones.

El liberalismo que inspira la Constitución esboza un proyecto de Estado contrapuesto al del Antiguo Régimen: estamental (Iglesia, nobles, militares, órdenes monásticas, gremios), oligárquico, reminiscencias feudales en la que proliferan los privilegios, de poder fragmentado por la nobleza, con multitud de jurisdicciones. El Estado absolutista no es más que un proyecto, posee la cabeza potente en Madrid y unas anoréxicas extremidades incapaces de vertebrar el te-

${ }^{17}$ Cita tomada de: MARTÍN RETORTILLO BAQUER, Lorenzo, Notas para la historia de la noción de orden público, Estudis i recerques, Policía y Constitución, Serie Protección ciudadana ${ }^{\circ}$ 1, Ayuntamiento de Barcelona, 1987 
rritorio, dividido en los realengos, de jurisdicción real, y territorios de señorío, de la Iglesia o seculares.

La Iglesia, por un lado, y el Ejército, por otro, fueron las dos instituciones de las que se valió el rey para procurar una mínima cohesión nacional, Este último se utilizó por el monarca como instrumento para contrarrestar el poder del señorío

La Constitución de Cádiz no significa una ruptura radical con el pasado ni mucho menos tiene el origen revolucionario de la francesa de 1791, partió de una legalidad que fue renovada por los mismos diputados que estaban legitimados para hacerlo. En la forma, tiene cierto parecido con la transición de la dictadura a la democracia que se vivió en España a la muerte del general Franco.

\section{VI.- EL TEXTO DE 1812 Y EL ORDEN PÚBLICO}

Como se ha señalado anteriormente la autoridad del Rey se extiende a todo lo que conduce a la conservación del orden público en lo interior, y la seguridad del Estado en lo exterior. Lo que pone en sus manos un grueso paquete de facultades y atribuciones. Resulta contradictorio que una Constitución claramente inspirada en el liberalismo e influida por la Constitución francesa de 1791, considerada como de Monarquía moderada, atribuyera al monarca tanto poder. Era el absolutismo solapado que se escondía tras las fórmulas constitucionales $^{18}$. Como señala Martín-Retortillo, la utilización de la noción de orden público para delimitar los poderes del rey, tiene su origen en la Constitución francesa de 1791, más que jugar en la línea revolucionaria y democrática, más que seguir con fidelidad el espíritu constitucional, sirve para mantener poderes tradicionales, afianzar reminiscencias de corte absolutista.

Este fortalecimiento y casi sacralización de la figura real, se produce de manera inconsciente o inadvertida, en el Discurso Preliminar, después de manifestar que la soberanía está reconocida y proclamada del modo más auténtico y solemne y de afirmar que la Corona es electiva, que nadie puede aspirar al reino sin ser elegido, que el Rey debía ser nombrado por los obispos, magnates y el pueblo y que las le-

\footnotetext{
${ }^{18}$ RODRÍGUEZ BERMEJO, A, Laband y el Derecho Presupuestario del imperio alemán, Estudio Preliminar a la edición española de P. Laband, IEF, Madrid 1979, XXVII, XXIX, Cita tomada de MARTÍN-RETORTILLO BAQUER, Lorenzo, Notas para la historia de la noción de orden público, Estudis i recerques, Policía y Constitución, Serie Protección ciudadana n ${ }^{\circ}$ 1, Ayuntamiento de Barcelona, 1987
} 
yes se hagan por los que representan la Nación y por el Rey ${ }^{19}$, el ponente se pregunta: ¿Quién a la vista de tan solemnes, tan claras y tan terminantes disposiciones podría resistir todavía a reconocer como principio innegable que la autoridad soberana está originaria y esencialmente radicada en la Nación?

Detrás de estas declaraciones de principios parecen incoherentes los siguientes párrafos del mismo Discurso Preliminar: El Rey como jefe del Gobierno y primer magistrado de la Nación, necesita estar revestido de una autoridad verdaderamente poderosa, para que al paso que sea querido y venerado de su Reino, sea respetado y temido fuera de él por las naciones amigas y enemigas. Toda la potestad ejecutiva la deposita la Nación por medio de la Constitución en sus manos, para que el orden y la justicia reinen en todas partes, y para que la libertad y seguridad de sus ciudadanos pueda ser protegida a cada instante contra la violencia o las malas artes de los enemigos del bien público.

En una Constitución que intenta romper con el Antiguo Régimen, con el absolutismo, puede parecer un exceso revestir al Rey de una autoridad verdaderamente poderosa. Y como se establece a continuación (...) que el entendimiento humano se rinda a la experiencia y haga el costoso sacrificio de declarar suelta de todo cargo la figura del Rey, que por tanto debe ser sagrada e inviolable en obsequio del orden público, de la tranquilidad del Estado y de toda la posible duración de la institución magnífica de una Monarquía moderada.

Por dos veces se hace referencia al tema que nos ocupa, se justifica tan inmenso poder real para garantizar la libertad y seguridad de los ciudadanos y la sacralización del Rey, en obsequio del orden público. Es la cláusula de orden público la que posibilita mantener en el Rey tan potentes y múltiples atribuciones, dejándole con poderes desproporcionados, y escasamente conciliables, con el intento de establecer una Monarquía constitucional. Como advierte Martín Retortillo ${ }^{20}$ (...) la noción de orden público, como técnica jurídica de demarcación, juega aquí un papel de importancia relevante, derivado de constituir, precisamente, una cláusula general. Mención expresa, por tanto, e intento, lógicamente, de demarcación, pero por medio de uno de estos mecanismos... como son las cláusulas generales de habilitación.

\footnotetext{
${ }^{19}$ Lo que algunos autores entienden por soberanía compartida

${ }^{20}$ Cit., p 21
} 
No parece que el Discurso Preliminar se refiera a una misma figura o concepto cuando alude a la seguridad de las personas y al orden público. Da la sensación que, en cuanto a este último, está contemplando los disturbios callejeros, manifestaciones, altercados de relieve, mientras cuando lo hace a la libertad y seguridad de los ciudadanos, alude a la delincuencia. Nos lo aclara la nueva cita del Discurso Preliminar al referirse al Ejército: (el soldado) va a proteger y conservar con las armas, cuando sea llamado por la ley, el orden público en lo interior, y hacer respetar la Nación siempre que los enemigos de afuera intenten invadirla u ofenderla. No está pensando el ponente en soldados enfrentándose a las estafas, atracos y demás delitos, lo hace, precisamente, a las situaciones antes señaladas.

Esta distinción entre seguridad ciudadana y seguridad pública u orden público, aún no está definida con claridad en términos jurídicos. Ni la legislación vigente en la actualidad ni las sentencias del Tribunal Constitucional son totalmente clarificadoras a la hora de concretar estos conceptos.

Parece claro que, en la CE de 1812, la autoridad llamada a proteger el orden público es el Rey y el instrumento del que se ha de valer, es el Ejército. Nada nuevo en la viña de una España en que el régimen señorial permanece intacto durante el siglo de la ilustración durante el cual el Ejército se convirtió en el elemento integrador del Estado y fundamento del sistema de seguridad. La Constitución de 1812 no aporta nada nuevo al respecto, no hace más que consolidar la institución militar como la columna vertebral de la patria. Conviene aquí recordar las palabras de López Garrido ${ }^{21}$ : Hablar de liberalismo progresista es, de entrada, un gesto un tanto atrevido. Porque en España el liberalismo "por cuyas obras se le conoce» no es el progresista, sino el conservador, achacable a la falta de identidad de la burguesía, su trayectoria vacilante, la desafortunada experiencia del poder liberal.

Lo cierto es que se vincula el Ejército con el mantenimiento y restablecimiento de orden público y, con ello, se da pie a la injerencia militar en la vida civil. Tampoco es nada nuevo, pero la Constitución de 1812 no hace gran cosa por evitarlo. No podemos dejar de advertir que ni antes ni muchos años después, hubo en España unas fuerzas específicas de seguridad capaces de enfrentase a los problemas de orden público. Para luchar contra la delincuencia, o sea, proteger la seguridad de las

${ }^{21}$ LÓPEZ GARRIDO, Diego, La Guardia Civil y los orígenes del Estado centralista, Crítica, Grupo Editorial Grijalbo, Madrid, 1982 
personas, constituye el artículo 356, como veremos más adelante, la Milicia Nacional.

\section{VII.- EL SISTEMA DE SEGURIDAD, LA POLICÍA Y LA JUSTICIA}

\section{VII.1.- El sistema de seguridad}

El concepto de Estado constitucional se caracteriza por una tensión entre los impulsos centralizadores y los de sentido contrario, descentralizadores. Por un lado, su espíritu progresista le lleva a potenciar el poder local, instituyendo la elección del alcalde y suprimiendo la figura del Corregidor de concepción absolutista, poniendo bajo la autoridad de aquél la Milicia Nacional, pieza básica, en el andamiaje del Estado liberal. Fortaleciendo el poder local y eligiendo los acaldes por votación, con la participación popular, se propone desplazar a las oligarquías locales. Por otro, y esto será importante para la organización del sistema de seguridad, se instituye la nueva figura del Jefe Político en cada Ayuntamiento y en cada provincia, dependientes del Ministerio del Interior, con atribuciones semejantes a las del gobernador civil, que se conocería más tarde. El liberalismo pretende de esta manera controlar el poder local y, también, extender el principio principal del liberalismo: la igualdad entre todos los ciudadanos. Para ello se hacía preciso que llegaran a todos los rincones de España las nuevas leyes y que todos fueran iguales ante ellas. Pero inevitablemente entra en una contradicción con la que conviviría durante los cortos periodos en que se mantuvo en vigor.

El Artículo 309 de la CE de 1812 determina que para el gobierno interior de los pueblos habrá ayuntamientos compuestos de alcalde o alcaldes, regidores y procurador síndico, presididos por el jefe político donde lo hubiere, y en su defecto por el alcalde o el primer nombrado entre éstos, si hubiere dos. Al poder local se le atribuyen competencias, especialmente en lo que se refiere a la administración civil en su jurisdicción, incluido el orden público y la protección de personas, y, además, la recaudación fiscal, por delegación del Estado. Pero la principal herramienta de poder que se pone en manos de los alcaldes es la Milicia Nacional2 ${ }^{22}$. Si el jefe político tiene la atribución de requerir las fuerzas militares para mantener o restablecer el orden público ${ }^{23}$, el al-

${ }^{22}$ El artículo 362 de la Instrucción para el Gobierno económico-político de las provincias de 1813 determina que habrá en cada provincia cuerpos de milicias nacionales, compuestos de habitantes de cada una de ellas, con proporción a su población y circunstancias 
calde disponía de una fuerza que contrarrestaba el poder del Jefe Político central, que constituyó, en palabras de López Garrido ${ }^{24}$, el soporte básico y el factor más dinámico, con más empuje, de la acción de rompimiento con el Antiguo Régimen, en ese proceso que abarca 1810-1843. Así, la postergación de la Milicia en los momentos de reacción absolutista, pero sobre todo a partir de 1843, será el síntoma de la derrota del proyecto político progresista.

Los jefes políticos eran unos agentes o delegados del poder central y pieza fundamental en el sistema de seguridad. El artículo 324 de la Constitución, señala que el gobierno político de las provincias residirá en el jefe superior, nombrado por el Rey en cada una de ellas. Respecto a las provincias, el artículo 325, determina que en cada una habrá una diputación llamada provincial, para promover su prosperidad, presidida por el jefe superior. El siguiente artículo se refiere a su composición: el presidente, el intendente y siete individuos elegidos.

Las atribuciones y condiciones que señala para los Jefes Superiores Políticos, en materia de seguridad y orden público, la Instrucción para el Gobierno económico-político de las Provincias de 1813, son las siguientes: (art. 135) en él recaerá la autoridad superior para cuidar de la tranquilidad pública, del buen orden, de la seguridad de las personas y bienes y de sus habitantes, la ejecución de las leyes, decretos y órdenes y en general de todo lo que corresponda al orden público para mayor prosperidad de la provincia. Para ello podrá requerir el auxilio de la tropa ${ }^{25}$. El art.136, determina que el mando político y el militar pueden unirse temporalmente en el caso de que la plaza se sienta amenazada del enemigo o cuando el Gobierno lo juzgue necesario para la tranquilidad y seguridad. Entre otras condiciones que se exige para ser Jefe Superior está la de tener aptitud y adhesión a la libertad política y a la independencia de la $\mathrm{Na}$ ción (art 137). Por ser los Jefes Superiores los primeros agentes delegados del poder ejecutivo, podrán ejercer las facultades que el párrafo 11 del art. $172^{26}$ de la Constitución concede al Rey .

\footnotetext{
${ }^{23}$ Atribuir a los alcaldes esta potestad produjo en las Cortes encendidas defensas y sus contrarias, Las críticas procedían de los diputados militares que no estaban dispuestos a que unidades militares dependieran del jefe civil, La balanza en las Cortes se saldó a favor del Jefe Político, pero en la práctica, el Ejército, valiéndose de su dependencia del Rey, actuaba según le pareciera, También tuvo sus críticos entre los que consideraban que invadía la autonomía municipal,

${ }^{24}$ LÓPEZ GARRIDO, Diego, La Guardia Civil y los orígenes del Estado centralista, Crítica, Grupo Editorial Grijalbo, Madrid, 1982

${ }^{25}$ El artículo 356 de la Instrucción para el Gobierno económico-político de las provincias de 1813, señala que habrá una fuerza militar nacional permanente, de tierra y de mar, para la defensa exterior del Estado y la conservación del orden interior

${ }^{26}$ Se refiere a las detenciones
} 
La citada instrucción atribuye al Jefe Político en los Ayuntamientos las siguientes competencias en materia de orden público: el gobierno de cada pueblo estará a cargo de sus respectivos alcaldes bajo la dependencia del Jefe Político (art. 49). Deberá llevar a efecto las medidas que juzgue necesarias para la conservación de la tranquilidad y del orden público, y para asegurar la propiedad y las personas de los vecinos (art. 51). Obliga a los alcaldes, por sí o a por sus ayudantes, rondar los lugares públicos para evitar excesos y desórdenes, pudiendo solicitar colaboración de los vecinos, para la conservación del orden público y la protección de las personas (art. 55). Dispondrá de la Milicia Nacional cuando sea necesario para el objeto de sus atribuciones, pudiéndose valer para reconocer los caminos, perseguir y aprehender malhechores, vagos y mal entretenidos y para las demás medidas de buen orden (art. 56). Podrá pedir el auxilio de tropa que se halle en su distrito al comandante militar (art.57). Cuando sepa que hay ladrones o malhechores en su pueblo, deberá avisar a los alcaldes de los colindantes, dando cuenta de todo al Jefe Político (art. 58). Se atribuye a los alcaldes facultades para llevar a cabo las primeras diligencias para remitirlas al juez competente, en relación a la comisión de hechos delictivos como robos, homicidios y demás. En esta función no dependen del Jefe Político (art. 60). Serán jueces de paz en sus municipios (art. 61). Corregirán los actos contrarios a la moralidad e impedirán toda reunión que pueda oponerse a ella o perturbar el orden (art. 63). Ejecutarán las penas prescritas en vía gubernativa por la infracción de policía y bandos de buen gobierno (art. 64). Cumplirán las órdenes que prescriban los Jefes Políticos.

El sistema de seguridad que diseña la Constitución situa al Rey en el vértice y sobre él descansan, a la vez que la jefatura del poder ejecutivo, las atribuciones sobre el orden público. Bajo su directo mandato está el Ejército, instrumento para mantener y restablecer el orden público y, también, a través del Ministerio del Interior, la red de cargos políticos locales, que tienen atribuciones de orden público, bajo su dirección, está la Milicia Nacional.

\section{VII.2.-La policía}

En cuanto a la institución policial, las deliberaciones tanto en los trabajos y ponencias previas a la propia Constitución como de la Instrucción para el Gobierno económico-político de las provincias, no le dedican especial atención. La necesidad de la Policía como Institución no parece sentirse demasiado...porque se partía del supuesto de que el orden público 
y la tranquilidad serían poco alterados y, por lo tanto, se haría innecesario tomar medidas excepcionales y normales para su conservación. El problema de la policía en un país en guerra ocupó un lugar muy modesto y tampoco pudo quedar muy bien definido y perfilado ${ }^{27}$.

Las discusiones sobre el papel de la policía versaron sobre su necesidad, funcionamiento, funciones a asignarle, control para evitar abusos de poder, la separación de las funciones policiales de las judiciales y de otras funciones administrativas. La innovación en materia de policía fue la creación de la Milicia Nacional.

La Milicia Nacional es creada por la Constitución en el Título VIII, art. 356, como se ha dicho; el art. 363, determinaba que se regularán mediante ordenanza particular el modo de su formación, su número y especial constitución en todos sus ramos; y en el siguiente se señalaba que el servicio de estas milicias no será continuo, y sólo tendrá lugar cuando las circunstancias así lo requieran.

Una de sus características principales fue su marcado arraigo popular, sus miembros eran ciudadanos que compatibilizaban su profesión con la de miliciano. Por otro lado, el nuevo cuerpo da la vuelta al concepto de seguridad del Estado absolutista basado en el Ejército y cuerpos de seguridad dependientes del poder central. La Milicia Nacional construye el modelo policial desde la base, los Ayuntamientos, aunque, eso sí, serán dirigidos por el jefe político dependiente del gobierno central. Se repite la misma tensión en este punto que la Constitución de 1812 soporta en otros: pretende dejar atrás las instituciones del Antiguo Régimen, pero parece temer hacerlo del todo. Ya hemos dicho que la Constitución no respondió a ningún proceso revolucionario, de ahí estas tensiones. Otra de sus características fue su marcado carácter político, la Milicia Nacional se constituyó para la defensa de la Constitución liberal y luchar contra sus enemigos políticos. También la define su carácter nacional pues extiende sus funciones a todo el país.

A pesar de representar un contrapoder al Ejército dependiendo de las autoridades civiles, sin embargo se establece la definición de sus funciones junto a las del Ejército, su organización estaba militarizada y sus miembros tenían la condición de militar siempre que vistieran de uniforme y estuvieran de servicio. Lo cierto es que el nuevo cuerpo se utilizaba igualmente para mantener el orden y la tranquilidad en las

27 TURRADO VIDAL, Martín, La Policía en la Historia Contemporánea (17661986), Ed. Dykinson, Ministerio del Interior, 2000 
ciudades que para perseguir y luchar contra las partidas enemigas realistas. Con el tiempo la Milicia Nacional se escindió en Milicia Nacional Voluntaria, unidades armadas que actuaban como fuerzas auxiliares del ejército y Milicia Nacional dedicada a funciones de seguridad exclusivamente en sus respectivas jurisdicciones. Ello no fue óbice para que los milicianos votaran para elegir a sus oficiales y que las dependencias oficiales del cuerpo sirvieran como foro de debate político.

Según López Garrido: El control de la Milicia Nacional por los Ayuntamientos compensa la dinámica centralizadora del jefe político. La Milicia nacional es hija de la eclosión liberal. La milicia Nacional fue indudablemente el soporte básico y el factor más dinámico, con más empuje, de la acción de rompimiento con el Antiguo Régimen, en ese proceso que abarca 1810-1843. y en otro lugar afirma que Las milicias fueron la fuerza de choque del liberalismo. Su identificación ideológica progresista es creciente.

El autor, a parte de esta dimensión de la defensa armada del cambio político, señala otras tres. Una es la ayuda que la Milicia prestó a la trasformación socioeconómica: desamortización y desvinculación, otra dimensión es la salvaguarda del orden público y, en especial, en la lucha contra las partidas realistas; y por último, La Milicia es un factor que impulsa la constitución de un Estado descentralizado basado en el poder municipal.

La identificación ideológica con el liberalismo fue un inconveniente para su funcionamiento La Milicia Nacional estuvo dominada por los elementos más exaltados y radicales desde el punto de vista ideológico. En palabras de uno de los líderes más radicales, Romero Alpuente, los exaltados se propusieron hacer de la Milicia «la Patria armada». Su incompatibilidad con el Ejército ordinario hizo imposible que sus mandos fueses reclutados de entre los cuadros del ejército y hubo que nombrar a los oficiales retirados. Eran frecuentes los actos de indisciplina y de insubordinación, por lo que la Milicia distaba mucho de ser una fuerza organizada y eficaz ${ }^{28}$. Incluso los Ayuntamientos electos, se vieron mediatizados por la Milicia Nacional.

El Reglamento de la Milicia Nacional, promulgado el día 15 de abril de 1814, la organizaba en pelotones, compañías, batallones y regimientos de infantería y caballería. Se exigía a los milicianos contar entre 30 y 50 años, trabajaban a tiempo parcial. Se les encomendaban las siguientes funciones: guardar los edificios públicos, patrullar para

${ }^{28}$ SÁNCHEZ MANTERO, Rafael, La Milicia Nacional, Reinado de Fernando VII, Arlanza, Madrid 2001 
garantizar la seguridad pública, perseguir y aprehender en el pueblo y en su término a los desertores y malhechores, escoltar las conducciones de presos y caudales públicos y defender los lugares y términos de sus pueblos de los enemigos interiores o exteriores de la seguridad y tranquilidad. Como se ve, son una mezcla de funciones policiales y militares, que habilitó para desempeñar funciones propias de policía local y de fuerzas auxiliares del Ejército.

\section{VII.3.- La justicia}

El poder judicial se configuraba como independiente, lo que significaba un avance fundamental, pese a que el Rey se reservaba el derecho de nombrar a los jueces. Agustín Argüelles, en su discurso ante las Cortes el 18 de agosto de 1811, se expresaba en los siguientes términos: "La experiencia ha demostrado hasta la evidencia que no puede haber libertad ni seguridad, y por lo mismo, justicia ni prosperidad, en un Estado en donde el ejercicio de toda autoridad está reunido en una sola mano. Su separación es indispensable».

Se establecían diferentes instancias judiciales para recurrir, a modo de segunda instancia judicial, se daba publicidad al proceso penal y se anunciaba la promulgación de un solo código de leyes penales y civiles y otro de Comercio. Era ésta una cuestión fundamental dada la gran cantidad de leyes que ensombrecían el caótico ordenamiento jurídico español. Sin embargo la Constitución no acaba del todo con las jurisdicciones especiales. Así, en el Discurso Preliminar se dice: Del mismo modo - antes se ha referido a los clérigos- ha creído indispensable dejar a los militares aquella parte del fuero particular que sea necesario para conservar la disciplina y subordinación de las tropas en el Ejército y Armada. Pero también reconocer que sólo la Ordenanza es capaz de arreglar este punto tan importante, de modo que se concilien el objeto de la institución militar y el respeto debido a las leyes de las autoridades. El soldado es un ciudadano armado solamente para la defensa de la Patria; un ciudadano que sorprendiendo la tranquila e inocente ocupación de la vida civil, va a proteger y conservar con las armas, cuando es llamado por la ley, el orden público en lo interior, y hacer respetar la Nación siempre que los enemigos de afuera intenten invadirla u ofenderla.

Se reestructuran los tribunales y se crean las Audiencias, los juzgados de primera instancia y los Juzgados de paz. El artículo 242 dispone que la potestad de aplicar las leyes en las causas civiles y criminales pertenece exclusivamente a los tribunales y el artículo 
280 establece que no se podrá privar a ningún español del derecho a terminar sus diferencias por medio de jueces árbitros, elegidos por ambas partes. El $21^{\circ}$ Acuerdo (fechado el 14 de enero de 1810), suscrito por Manuel de Lardizábal, José Pablo Valiente, Antonio Ranz de Romanillos, Alejandro Dolarea y D. Agustín Argüelles, establece que: Para asegurar la libertad individual de los ciudadanos contra el abuso del poder y autoridad del gobierno, ha acordado la Junta que se cree a la reunión de las Cortes un Tribunal extraordinario con el nombre de Tribunal de Agravios, a semejanza del que había en Aragón llamado Greuges, compuesto de nueve Jueces, adonde se llevarán las quejas contra los funcionarios públicos por razón de los actos cometidos en el ejercicio respectivo de sus cargos contra la Constitución y contra las leyes que directamente aseguran o protegen la libertad personal de los ciudadanos. Las Cortes formarán una lista doble de Jueces tomados de todos los Tribunales del Reino, de la cual el Rey elegirá los nueve que han de componer dicho Tribunal. Su autoridad y facultades se determinarán más adelante (...).

El Título V del texto constitucional establece, entre otros aspectos, que la potestad de aplicar las leyes en las causas civiles y criminales pertenece exclusivamente a los Tribunales; que ni las Cortes ni el Rey podrán ejercer en ningún caso las funciones judiciales, abogar causas pendientes, ni mandar abrir los juicios fenecidos, que las leyes señalarán el orden y las formalidades del proceso, que serán uniformes en todos los Tribunales, y ni las Cortes ni el Rey podrán dispensarlas. Que los Tribunales no podrán ejercer otras funciones que las de juzgar y hacer que se ejecute lo juzgado; tampoco podrán suspender la ejecución de las leyes, ni hacer reglamento alguno para la administración de justicia. Ningún español podrá ser juzgado en causas civiles ni criminales por ninguna comisión, sino por el Tribunal competente, determinado con anterioridad por la Ley; en cuanto a los negocios comunes, civiles y criminales no habrá más que un sólo fuero para toda clase de personas.

Señala los fueros especiales: los eclesiásticos continuarán gozando del fuero de su estado, en los términos que prescriben las leyes o que en adelante prescribieren; los militares gozarán también de fuero particular, en los términos que previene la ordenanza o en adelante previniere. Para el nombramiento de los magistrados o juez se requiere haber nacido en el territorio español, y ser mayor de veinticinco años y no podrán ser depuestos de sus destinos, sean temporales o perpetuos, sino por causa legalmente probada y sentenciada, ni suspendidos sino por acusación legalmente intentada. En el supuesto de que llegaren al Rey quejas contra algún magistrado, y formando 
expediente, parecieren fundadas, podrá, oído al Consejo de Estado, suspenderle, haciendo pasar inmediatamente el expediente al Supremo Tribunal de Justicia, para que juzgue con arreglo a las leyes. El texto continúa señalando las responsabilidades penales de los jueces con ocasión de la infracción de la ley y, en especial, por los delitos de soborno, cohecho y prevaricación.

La justicia se administrará en nombre del Rey y las ejecutorias y provisiones de los Tribunales Superiores se encabezarán también en su nombre. Se declara que el Código civil y criminal y el de Comercio serán los mismos para toda la Monarquía, sin perjuicio de las variaciones que por particulares circunstancias puedan hacer las Cortes.

Establece el Tribunal Supremo de Justicia para, entre otras atribuciones: a) dirimir todas las competencias de las Audiencias entre sí en todo el territorio español y de las Audiencias con los Tribunales especiales que existan en la Península e islas adyacentes. b) Juzgar a los secretarios de Estado y de Despacho cuando las Cortes decretaren haber lugar a la formación de la causa. c) Conocer de todas las causas de separación y suspensión de los Consejeros de Estado y de los Magistrados de las Audiencias. d) Conocer de las causas criminales de los Secretarios de Estado y de Despacho, de los Consejeros de Estado y de los Magistrados de las Audiencias, correspondiendo al jefe político más autorizado la instrucción de la causa quien, una vez concluida, remitirá lo actuado al alto Tribunal para su enjuiciamiento y fallo.

Todas las causas civiles y criminales se resolverán dentro del territorio de cada Audiencia correspondiendo a las Audiencias conocer, en todas las causas civiles y criminales conocidas e instruidas por los Juzgados inferiores de su demarcación, en segunda y tercera instancia.

Se establecerán partidos proporcionalmente iguales, y en cada cabeza de partido habrá un juez de letras con un juzgado correspondiente. En todos los pueblos se establecerán alcaldes, y las leyes determinarán la extensión de sus facultades, así en lo contencioso como en lo económico. Las leyes decidirán si ha de haber Tribunales especiales para conocer determinados negocios.

Los magistrados y jueces, al tomar posesión de sus plazas, jurarán guardar la Constitución, ser fieles al Rey, observar las leyes y administrar imparcial justicia. 


\section{VIII.- CONCLUSIONES}

En el periodo histórico que abarca este estudio hemos podido verificar la existencia de dos conceptos opuestos de orden público. El que se resiste a ser desplazado, que corresponde al Antiguo Régimen, concebido como fin es sí mismo, más preocupado y ocupado en el cuidado de quienes ostentan el poder como instrumento para mantener los privilegios de clase, que en garantizar la seguridad de la ciudadanía. Era una imposición del Estado a los ciudadanos por el que se les procuraba cierta seguridad a cambio de adaptar su conducta a las normas establecidas. No existe división de poderes y el Estado ejerce un gran control sobre los nacionales, sin que éstos puedan influir en la forma de ser gobernados.

El Estatuto de Bayona que pretende instaurar en España José I, venía influenciado por los principios de la Revolución Francesa, de sus ideas del liberalismo burgués, lo que representaba un paso adelante muy significativo en cuanto a la concepción del orden público, por lo que se refiere a la situación en España. La constitución de 1812, siguiendo al profesor Oscar Alzaga: es la réplica liberal y patriótica a la Carta de Bayona. La Constitución del 12 es la más progresista de su época, el catecismo político de los liberales europeos perseguidos, que se difunde, más o menos clandestinamente, desde Burdeos hasta San Petersburgo, llegando a ponerse en vigor integramente en el Reino de las Dos Sicilias. Pese a no romper con el Antiguo Régimen de forma clara y contundente, establece la noción de orden público propia del Estado Liberal, en la que priman la libertad sobre la seguridad, respeto a los derechos y libertades públicas, el reconocimiento de la división de poderes. Los sistemas de seguridad y sus instituciones, se constituyen, en cada caso, para responder a los principios que lo inspiran. 